An Engineering Data Book 


\title{
An Engineering Data Book
}

\author{
Edited by \\ JR Calvert and RA Farrar
}


(C) Dr J. R. Calvert, Professor R. A. Farrar, University of Southampton 1999

All rights reserved. No reproduction, copy or transmission of this publication may be made without written permission.

No paragraph of this publication may be reproduced, copied or transmitted save with written permission or in accordance with the provisions of the Copyright, Designs and Patents Act 1988, or under the terms of any licence permitting limited copying issued by the Copyright Licensing Agency, 90 Tottenham Court Road, London W1P 0LP.

Any person who does any unauthorised act in relation to this publication may be liable to criminal prosecution and civil claims for damages.

The authors have asserted their rights to be identified as the authors of this work in accordance with the Copyright, Designs and Patents Act 1988.

First published 1999 by

MACMILLAN PRESS LTD

Houndmills, Basingstoke, Hampshire RG21 6XS

and London

Companies and representatives

throughout the world

ISBN 978-0-333-51661-4

ISBN 978-1-349-11310-1 (eBook)

DOI 10.1007/978-1-349-11310-1

A catalogue record for this book is available

from the British Library.

$\begin{array}{llllllllll}10 & 9 & 8 & 7 & 6 & 5 & 4 & 3 & 2 & 1\end{array}$

$\begin{array}{llllllllll}08 & 07 & 06 & 05 & 04 & 03 & 02 & 01 & 00 & 99\end{array}$

This book is printed on paper suitable for recycling and made from fully managed and sustained forest sources. 


\section{Contents}

1. Symbols and Units

2. Physical Constants

3. Analysis

4. Analysis of Experimental Data

5. Mechanics

6. Properties and Mechanics of Solids

7. Properties of Materials

8. Thermodynamics and Fluid Mechanics

9. Automatic Control

10. Electricity and Magnetism

11. Soil Mechanics

12. Structures

13. Symbols Index

14. Keyword Index 


\section{Preface}

Learning formulae is the bugbear of the student, and many avoidable errors, both in education and professional practice, have been made through the incorrect recall of formulae or numbers. This booklet aims to provide a ready reference for commonly required formulae and data, for use in coursework and examinations (where permitted) and in professional practice. It is not a textbook - the user is expected to know when to use a particular formula, and just as important, when not to use it.

The units used are SI, or multiples, with conversion factors from other systems provided. The symbols are generally those in common use in particular specialities, except where this would cause confusion in context in a particular section of the book. A complete list of symbols, with meaning and units, is included.

This edition is an extended and revised version of that edited by AJ Munday and RA Farrar, published in 1979 in collaboration with The Macmillan Press Ltd, itself based on an internal publication of the Department of Mechanical Engineering, University of Southampton.

Data have been collected from a large variety of sources, and the editors are grateful to many colleagues, past and present, for their contributions and suggestions.

The editors have made every effort to ensure the accuracy of this data,but cannot guarantee it. No responsibility can be taken for the consequences of any errors which may remain. Any person finding an error is asked to inform the publishers. 